$$
\begin{array}{lll}
26 & \\
A & 3
\end{array}
$$




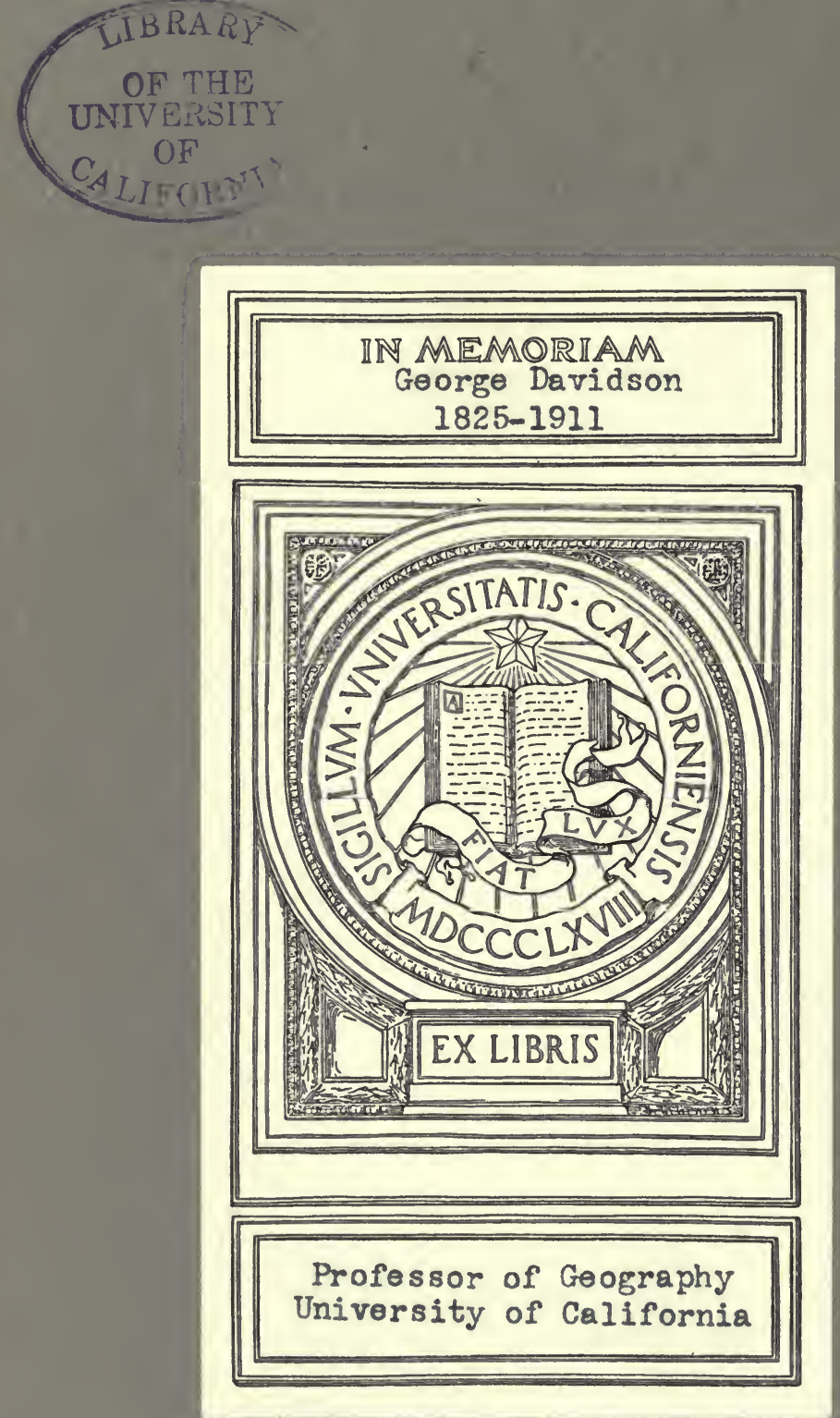




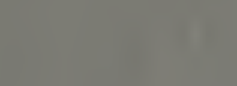

1 



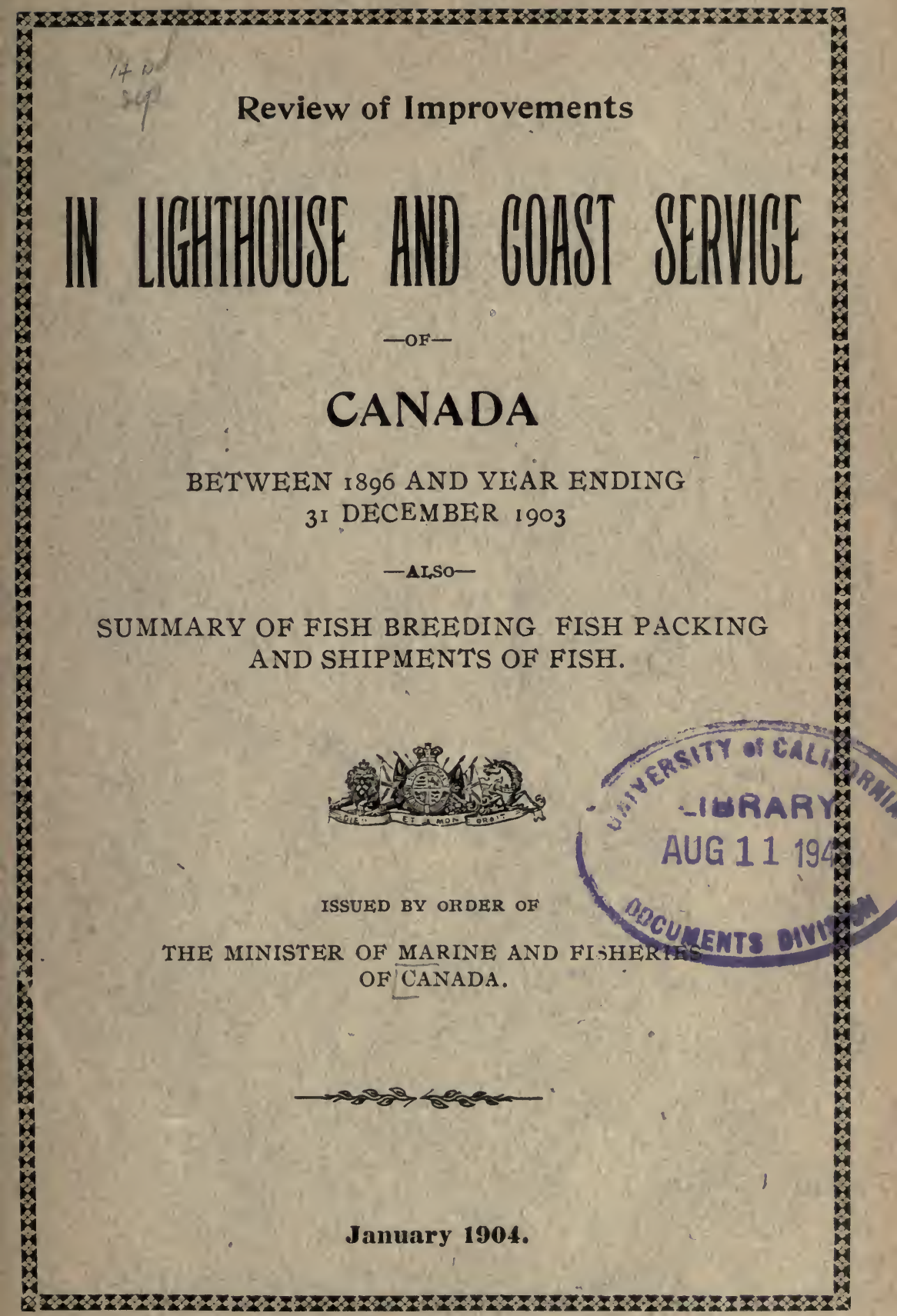





\section{Review of Improvements}

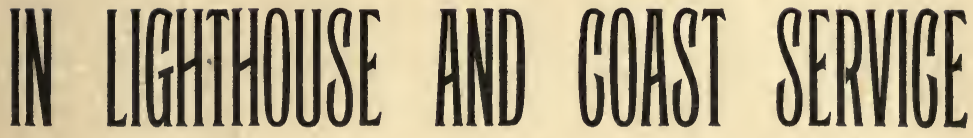 - $\mathrm{OF}-$}

\section{CANADA}

BETWEEN I 896 AND YEAAR ENDING

3I DECEMBER 1903

-ALSO-

SUMMARY OF FISH BREEDING, FISH PACKING AND'SHIPMENTS OF FISH.

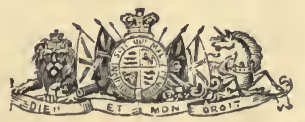

ISSUED BY ORDER OF

THE MINISTER OF MARINE AND FISHERIES OF CANADA. 
Digitized by the Internet Archive in 2007 with funding from OAticrosoft Corporation anterine 


\section{$V K 26$ $A 3$}

Review of the Progress and Development of the Department of Marine and Fisheries since 1896, and Comtemplated Improvements.

This pamphlet is prepared with a view of presenting to the public, evidence of the great progress and improvements made in connection with both branches of the important Department of Marine and Fisheries, of Canada. Many persons interested in our great waterways and fisheries, who have not the time or opportunity to read elaborate and detailed annual reports, will find in this summary, the information which has so frequently of late, formed the subject of enquiry. Besides, the number of annual reports published by Parliament is limited, and, therefore, the interested public cannot fail to appreciate this effort to chronicle the progress in aids to navigation and fish breeding.

New Aids to Navigation and Improvements during the rast Six Years.

Owing to the adoption of a more liberal policy during the past six or seven years, many improvements in lighting apparatus and fog-alarms, have been introduced. The increased trade of the past six years, on the coast, ocean and inland waters of Canada, demanded more and better aids to navigation, and the requirements of the shipping interest, mariners and fishermen, have been considered.

The following comparative statement shows the increased total expenditure during the year 1903 over 1896 . 
Comparative Statement of Total Expenditure for the Fiscal Years 1896 and 1903.

I 896

1903

Ocean and River service $\$ 181,451$.7I Ocean and River service $\$ 415,688.08$ Lighthouse and Coast " $466,057.55$ Lighthouse and Coast “ $968,697.76$ Scientific Institutions... 81,699.92 Scientific Institutions... $125,155.79$ Marine Hospitals ..... 36,683.36 Marine Hospitals..... 4 48,822,99 Steamboat Inspection.. 26,321.27 Steamboat Inspection .. 32, I43.90 Civil Govern. Salaries.. 70,703.71 Civil Govern. Salaries.. · 74,050.00

Total...... $\$ 862,917.52$

Total.........\$1,664 558.52

It will be observed that the largest increase in expenditure is in connection with Ocean and River Service, and Lighthouse and Coast Service of Canada, caused by the corresponding increase of lighthouses, fog-alarms, steamers and buoys and the general expansion and effectiveness of the service.

The following statement in detail, conveys some idea of the great attention given in recent years, to the several branches of this service and the cost involved.

\section{Comparative Statement of Expenditure for Lighthouse and loast Service for the Years 1896 and 1903.}

1896

Salaries \& allowances

of Lightkeepers.. \$199,348.6I

Maintenance \& repairs

to lights........ 225,691.07

Construction of lights

Agencies, rents and

contingencies....

Signal service........

Repairs to wharves.. $\mathrm{r} 7,662.28$

$15,372.14$

$5,338.76$

$2,644.69$
1903

Salaries \& allowances of Lightkeepers..

Maintenance \& repairs to lights.........

Construction of lights. Agencies, rents and contingencies .... Signal service.........

Repairs to wharves.... Salaries of temporary

Officials..........
$\$ 222,879 \cdot 38$ $305,632.20$ $405,342.42$

I9.366.I4

$6,895 \cdot 75$

I,735.9I

$6,845 \cdot 96$

$. \$ 968,697.76$

Tota1.........\$466,057.55

Total.

The total cost of maintenance of Lighthouse and Coast Service in 1896 was $\$ 448,395.27$, and construction of lights $\$ 17,662.28$, total in $1896 \$ 466,057.55$; and for the year 1903 , 
maintenance, $\$ 563,355.34$, construction, $\$ 405,342.42$, total in I $903, \$ 968,697 \cdot 76$.

The additions and improvements, are the result of careful consideration of the wants of navigation, from year to year, but the additions made during the year 1903, is most noticeable, arising from the applications for lighthouses and fogalarms and the progressive policy adopted by the present administration.

Since the year 1896 one hundred and fifty-six towers and enclosed Lighthouses have been built and fifty Pole Lights have been erected, making a total of two hundred and six new lights put in operation.

The following table will show the number of new lights established in each district.

New Brunswick, . . 5 Lighthouses, and 12 Pole Lights, Nova Scotia,..... . 34 do " 4 do P. E. Island, ... 15 do " I do Quebec,...... 38 do " 6 do Ontario and

above Montreal, . 44 British Columbia, . . 20

do do

$\begin{array}{ccc}\text { " } 23 & \text { do } \\ & 4 & \text { do } \\ 50 & \end{array}$

In addition to this, a number of lights are about completed, and will be put in operation next spring. Tenders have been invited for several more.

Lighthouses to be put in Operation Next Spring and others for which Tenders have been Invited.

New Brunswick, . . 2 buildings erected, lights to be put in operation next spring,

do

I fog-alarm building under construction. 
Nova.Scotia, . . . 4 buildings erected, lights to be put in operation next spring,

do

4 buildings under construction,

Quebec, . . . . 8 new lighthouses to be put in operation next spring, which includes Lower Traverse lighthotise and Belle Isle fog-alarm. The Lower Traverse Pier and Lighthouse will cost in the vicinity of $\$ 95,000.00$. The Pier is completed and the Lighthouse under construction. The Belle Isle fogalarm building will cost about $\$ 20,000.00$.

Ontario,. . . . 7 new towers have been erected and will be put in operation next spring.

British Columbia.. I lighthouse under construction.

Total . . . 27

These figures will increase the number of lighthouses built since the year 1896 to 183 , adding 50 pole lights erected, will make a total of 233 .

\section{Lightships Constructed.}

Two steel lightships, with the most approved equipment and illuminating apparatus, have been recently completed. One lightship has been placed upon the Lurcher Shoal, in the Bay of Fundy and will be a great aid to ocean going vessels and others making the harbour of St. John, N. B., during the present winter. The other lightship will be placed off the Island of Anticosti in the spring. These vessels have been built at a cost of ONE HUNDRED TBOUSAND DOLLARS EACH. 
Comparison of the Total Number of Lights in the Dominion of Canada, in the Years 1896 and 1903.

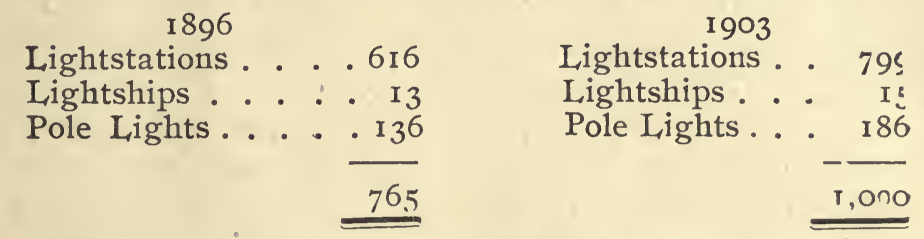

The fog-alarm stations operated by machinery are included in the above number. The number of fog-alarm stations for I 896 was 82 , and this number has been increased to 94 in 1903, six of the alarms are sirens operated by compressed air.

Improvements in Buoy Service in the St. Lawrence River Between Montreal and Quebec.

Previous to the spring of 1899 , the buoy service between Montreal and Quebec had been' performed under contract, but this system would not admit of expansion without constant changes in the contract price. A change was made by the purchase of the steamer "Shamrock," which was built and fitted with hoisting apparatus for buoy work, and the work placed specially in charge of an engineer appointed to maintain the' service.

Changes and Improvements in Buoys and Moorings.

Improvements have been made in classifying the steel buoys as first and second class, according to their importance and condition, and the spar buoys as first, second and third class. Each buoy is numbered under letters of the district to which it belongs, $Q$. Quebec district. C. Champlain district, L. Lake district, which includes Lake St. Peter, and M. Montreal district.

The anchors and mooring chains have been improved and a large number of inferior buoy's, have been replaced by new onés. About roo Martin patent anchors have been added since 1899 , to replace the old fashioned stock anchors, and the mushroom anchors have also been largely increased.

The spar buoys are swift current buoys, ballasted with cast iron rings to keep them upright. 
The total number of buoys maintained between Montreal and Quebec in round numbers is 250.

They are placed in the Spring and taken up in the Fall.

Changes Be'TWEen Quebec and Portneuf since i896. Elleven spar buoys added.

\begin{tabular}{|c|c|}
\hline " & $\begin{array}{l}\text { Portneuf and Montreal. Ten conical } \\
\text { buoys substituted for can buoys. }\end{array}$ \\
\hline " & $\begin{array}{l}\text { Lake St. Peter and Varennes. Eight can } \\
\text { buoys substituted for conical buoys. }\end{array}$ \\
\hline “" & $\begin{array}{l}\text { St. Augustin and Pointe aux Trembles. } \\
\text { Five can buoys substituted for spar } \\
\text { buoys. }\end{array}$ \\
\hline “" & $\begin{array}{l}\text { St. Augustin and Portneuf. Three can } \\
\text { buoys substituted for spar buoys. }\end{array}$ \\
\hline “" & $\begin{array}{l}\text { Quebec and Platon. Fourteen can and } \\
\text { conical buoys substituted for spar buoys. } \\
\text { The can and conical buoys above men- } \\
\text { tioned are all steel, the conical painted } \\
\text { red are starboard buoys and the can } \\
\text { painted black are port hand buoys, } \\
\text { according to the rules of the Depart- } \\
\text { ment. }\end{array}$ \\
\hline
\end{tabular}

Gas Buoys added in 1903

Owing to the introduction of acetylene gas by the Department, a large number of gas buoys were put in position in November last; the total number now between Montreal and Lake St. Peter is I6, but 12 of these were placed between Montreal and Sorel, for the benefit of the late arrivals among ocean going steamers. The advantage of these gas buoys has been said to be twofold, the steamers are enabled to proceed at night as well as during the day, going to and from Montreal without any unnecessary stoppage, during the autumn navigation. 


\section{Proposed Gas Buoys Between Batiscan and Port St. Francis.}

As before stated, acetylene gas has been introduced by the Department for gas buoys, and this will enable the Department to establish buoys after the opening of navigation more rapidly than the use of pintsch gas, which is made by special apparatus adapted to the pintsch gas only. The ship channel between Batiscan and Port St. Francis, will be lighted by gas buoys for a distance of 30 miles, as soon as the buoys can be procured.

\section{ENLARGING THE SCOPE OF THE DEPARTMENT.}

\section{Gas Buoys on the St. Lawrence River between Montreal and Kingston.}

The Department of Marine and Fisheries acquired from the Railways and Canals Department of Canada, 39 gas buoys and the steamer "Scout." These buoys have been maintained between Montreal and Kingston, by the Department of Marine and Fisheries and have given great satisfaction to the large number of vessels engaged in the carrying trade, from Montreal and other points on the St. Lawrence river.

Orders have been placed for II shallow draft spar gas buoys at a cost of $\$ 1,600$ each, to be put in position between Montreal and Kingston, and 13 of the same kind for the ship channel below Montreal.

\section{Gas Store Holders for Lighthouses between Montreal and Kingston.}

In addition to the gas buoys the Department is procuring 42 steel store holders for converting lighthouses between Montreal and Kingston into automatic gas lights, and 40 gas lanterns. 
Gas Buoys for other Localities.

Gas buoys for Halifax, Nova Scotia, have been ordered, one, a combined gas and bell buoy, will cost $\$ 2,700$. This will make 4 gas buoys leading into Halifax harbour. One combined gas and bell buoy has been ordered for Parry Sound harbour.

Buoys betweən Quebec and Gaspé on the St. Lawrence River.

50 Can and Conical Buoys.

I6 Gas Buoys.

Steel can buoys are now being made in the workshop of the Quebec Agency and a number of steel buoys, are being substituted for wooden can buoys.

\section{Steel Coast Buoys in Maritime Provinces and British Columbia, Canada.}

The expenditure on account of construction of steel buoys since 1896 , made by contract, amounts to about $\$ 53$, ooo. These buoys consist of automatic whistling buoys, Trinity pattern bell buoys, United States pattern bell buoys, conical and can buoys. The number made under contract is as follows :

Automatic Whistling Buoys, I r: Average cost

Trinity pattern without moorings $\$ 730$ each Trinity pattern bell buoys.. 8. do do 900 " U. S. pattern bell buoys.... I6. do do 545 Can buoys.................... 96. do do 104 Conical buoys.................. 82. do do 178 Swift Current buoys.......... r6. do do 230 " Made at Quebec Agency Workshop.................... ro. do do 200 "

Many of these buoys have been required to rep'ace buoys that disappeared, but a large number has been added to the list of steel buoys that were in position in 1896 . The coast steel buoys numbered 170 in the year 1896 and in 1903 they number 250, showing an increase of 80 steel buoys on the coasts of the Maritime Provinces and British Columbia These buoys are maintained in position by Dominion steamers. 


\section{Buoy Service on the Great Lakes and Georgian Bay,}

\section{Canada.}

There are 4 gas buoys and 5 bell buoys on the Great Lakes and Georgian Bay and a large number of wooden buoys.

\section{Total Number of Buoys in the Waters of the Dominion of Canada.}

The total number of buoys in the harbours, bays, rivers and lakes is about 3,700 made up as follows ;-

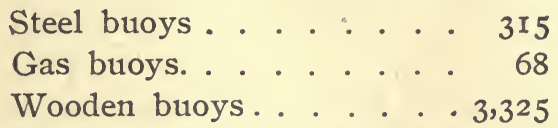

More important than merely the increase in the number of wooden buoys, is the increase in localities or harbours buoyed. The harbours and districts in the Dominion now buoyed number about 330, an increase since the year 1896 , of 50 districts.

\section{Ocean and River Service.}

The foregoing particulars relate to improvements in Light. house and Coast Service, but an equally remarkable increase in expenditure and efficiency in Ocean and River Service has taken place. The lighthouses and fog-alarms require periodical delivery of illuminants, coal and other supplies, and the Coast and St. Lawrence River buoys constant attention and renewing. Additional steamers have been built and others purchased, to effectively meet the requirements of the various branches of the service. Although all the steamers are not classed under Ocean and River Service, yet for convenience the steamers added to the fleet of Dominion steamers under the control of the Marine and Fisheries Department, is given in the following statement: The "I ady Laurier" was built to replace the "Newfield" which was wrecked on the coast of Nova Scotia. This steamer is equipped with the newest and most improved cablellaying and lifting gear, and will be used when necessary for cable work between Halifax and the Magdalen Islands. 


\section{Dominion Steamers Built and Purchased Since 1896.}

" Minto," built in . . . . I898-Winter service.

"BRANT," " .... I898-Lighthouse and buoy service.

"DRUID," “. .... I90I-02-Buoy service below Quebec on St. Lawrence River.

"LADY LAURIER," built . I90I-02-Lighthouse and coast service, Nova Scotia. "Shamrock," bought . . I 899-Buoy service between Montreal and Quebec on the St. Lawrence River.

"Scout," rebuilt.... I902-Buoy service between Montreal \& Kingston. "KeSTREL," built in . . . I90I-Fishery protection service, British Columbia.

"Georgia," “ ... I90I-Fishery protection service, British Columbia.

"BAYFIELD," bought . . IgoI-Hydrographic survey, Lake Superior.

"Gulnare," “ . . . I902-Tidal survey, Gulf St. Lawrence.

"Viator," " ....I903-Lighthouse and buoy service, St. Lawrence River.

“MaisonnkUVE," bought . .1903-Patrol steamer, St. Lawrence River.

"RhShRVE," bought . . . I903-For sweeping channel above Montreal, and buoy service.

Total cost of these steamers, $\$ 75 \mathrm{r}, 786.46$.

Total Expenditure for 0cean and River Service. 1896 . . \$I8I 45I.7I. I903 . . \$4I5,688.08

The largest item in this expenditure, viz., $\$ 280,376.06$, includes the maintenance and repairs to steamers and the payments for the steamers "Gulnare" and "Bayfield." 


\section{Tidal Survey.}

The Tidal Survey of the Dominion has again been resumed, with a view of gaining more correct knowledge regarding the strong currents of the St I,awrence River, Gulf of St. Lawrence, and Strait of Belle Isle. The work already done, establishes beyond a doubt, that tidal observations in published form, will be a valuable aid to navigation in the waters mentioned.

The ordinary mariner concludes that currents are influenced mainly by the winds, but the work now being accomplished proves that the movements of currents is reduceable to astronomical laws.

The steamer "Gulnare," which has been engaged in the Tidal Survey during the Summer of $\mathrm{IyO}_{3}$, was purchased at a very reasonable figure, and the officers of the survey have been enabled to carry on their observations without interruption, which was not the case when one of the ordinary supply steamers was used intermittently.

\section{Hydrographic Survey.}

The steamer "Bayfield," formerly the "Lord Stanley," was purchased at a cost of $\$ 50,00000$, and the sum of $\$ 10,000.00$ has been spent in thoroughly equipping this steamer. The "Bayfield" is a strongly built and powerful steamer; the additional expenditure has made the steamer the most complete Hydrographic Survey vessel ever employed on the Great Lakes by Canada or the United States.

The survey of Lake Superior was begun in 1902, but the old steamer " Bayfield" was unsuitable for the work and has been replaced by the new "Bayfield." The increased navigation on this Great Lake makes it necessary to chart dangerous sboals and rocks which have hitherto been unknown to navigators, and the charts with soundings will be prepared as the survey advances. 


\section{Life Saving Stations.}

In the year 1902 a new Life Saving Station was established at Long Point, Lake Erie. The building is a commodious one of two stories, the upper part being arranged with a living room and bed rooms for the crew. The kitchen and dining room form part of the lower portion of the building, and the life boat and equipment occupy a large space of 36 by 20 feet. The crew resides permanently at the station during the three Fall months. The boat is launched upon a tramway.

Point Pelee Life Saving Station was last year moved 200 yards from the extreme point, a new tramway built and repairs made to the building.

Several of the old style Dobbin selfrighting and bailing boats, which had become useless by decay, have been replaced by new surf boats. Seven new Beebe-McLellan selfbailing surf boats have been supplied to different stations since the year 1898 , at a cost of about $\$ 2,800$.

One new Life Saving Station was established at Kincardine, Ontario, during I903.

\section{Meteorological Service.}

The annual report upon Meteorological and Magnetic Service for 1903, has not been completed, but the report published last year shows ithe increase in persons in receipt of pay, the increase of stations and number of voluntary observers.

\section{Observers and Stations.}

$$
1896 .
$$

Observers paid and not paid 236

Stations.............. 236 Expenditure. $\$ 62,852.32$
1902.

Observers paid 78

Observers not paid 245 Stations.............. 323

Expenditure. $\$ 82,584.85$ 


\section{Experiments with Acetylene Gas.}

The gas buoys in the St. Lawrence River, between Montreal and Kingston, have been fitted with acetylene gas burners and holders. This gas has proven a more satisfactory illuminant than Pintsch gas for buoys so far as intensity is concerned; the lights on the buoys can be seen from a much greater distance and acetylene has also an advantage over the Pintsch gas, as acetylene gas can be conveyed from one point to another by the buoy tenders. The Pintsch gas is only available in two or three localities. The use of acetylene will enable the Department to locate gas buoys where it has been impossible in the past, because of the almost insuperable difficulty of procuring the Pintsch gas outside certain limited localities.

\section{Winter Mail Service between Prince Edward Island and the Mainland.}

With a view of improving winter communication between the Island and the mainland, the steamer "Minto" was built in 1898 and, with the steamer "Stanley" has been employed in the mail, passenger and freight service.

An accident occurred to the propeller blades of the "Minto" when going to the assistance of the "Stanley" last winter, but repairs have been made and the steamer is now in the winter work.

The "Stanley" has been extensively repaired and strengthened, in order to make her thoroughly efficient for the winter service. This steamer, has been remarkably successful as an ice steamer having been in service every winter since 1887. Her plates were indented between the frames about the water line, by contact with heavy ice, and these have been faired and intermediate frames and doubling plates put in the steamer. Her deck and wheel houses have been repaired and she is now"engaged in her winter work.

The steamers "Stanley " and "Minto," are powerful boats and have a speed of 15 or 16 knots each, the horse power being respectively 2,100 and 2,900 indicated. 


\section{Steamboat Inspection.}

The Steamboat Inspection Act relating to the inspection of machinery enacted in 1868, provides for the collection of steamboat inspection fees and in 1883 , hull inspection was included. The steamboat inspection fees last year amounted to $\$ 37,428.92$.

Représentations have been made to the Minister of Marine and Fisheries with a view of abolishing the steamboat inspection fees. An amendment to the Steamboat Inspection Act has been introduced in Parliament and when this Bill is passed the fees will be abolished.

\section{Annual Reports.}

The Annual Reports embrace a wide range of subjects, among which are, experiments in buoys and lighthouse illuminants, marine hospitals, harbours and harbour improvements, examination of masters and mates, registration of shipping, legislation and amendments of navigation laws, sick and distressed mariners and other subjects.

It should be borne in mind that this pamphlet does not contain more than a mere summary of the more important subjects in which rapid advancement in the operation of the Department of Marine and Fisheries, has taken place during the past six or seven years.

\section{Investigation into causes of casualties in the St. Lawrence.}

Owing to misrepresentation concerning this great waterway, to and from the sea, and ignorance of the causes which led to several casualties of ocean going steamers, investigations have been held. The result shows that the casualties were not due to lack of affective aids to navigation, nor dangers existing in the river, but in nearly every instance, to some eversight or neglect on the part of those in charge for the 
time being. Several investigations have been held by the Imperial Board of Trade, and the confirmation of the above statement is found in the fact that several Masters bolding Imperial Certificates have been suspended.

The pilotage system of the past has been defective, and this question is now receiving attention with a view of introducing a more complete and effective system.

\section{Extensive Coast Line.}

Owing to the extensive Coast Line of the Dominion on the Atlantic and Pacific oceans, the vast Inland Lakes and the increasing commerce, constant supervision must be exercised. This necessitates the employment of a large staff in the outside service. The employees in the lighthouse service, harbourmasters, wharfingers, shipping masters, surveyors and others have steadily increased until they number in the vicinity of 2050 , all of which receive directions from Ottawa.

\section{Naval Reserve and Navigation Schools.}

Navigation Schools where mariners may receive instruction in navigation will be established. Schools of this rature have not been in existence in Canada, and consequently seamen contemplating the study of navigation have been compelled to procure their education in private schools $\boldsymbol{w}$ here navigation is taught, or by studying without the assistance of teachers. The merchant marine of Canada contains a number of as fine seamen as can be found anywhere, but their facilities for the study of navigation have not been commensurate with the requirements of sailors or those who wish to become officers. The system and plan of operation, in connection with establishing and maintaining these schools, is now receiving attention by the department of Marine and Fisheries. It is expected that training schools will be established in the near future on board some of the Government ships, and there will be not only education given in navigation, but also training in seamanship. 
For several years past there has been in contemplation the formation of a naval reserve. The present fishery protection service and some other branches of the Marine steamer service will afford a nucleus upon which can be formed this naval reserve.

\section{Hudson Bay Expedition.}

The Hudson Bay Expedition undertaken this year, is following up the course pursued by the Department in previous years to secure information respecting the length of time the Hudson Straits are navigable and also for surveying purposes in Hudson Bay. This Expedition has been thoroughly equipped for a period of two and a half years in case the vessel may become ice-bound, but she is expected to return next October. The men are supplied with a complete supply of artic clothing.

The expedition will include geographical surveys, securing information respecting the kinds of fish that frequent the waters, and preventing any illegalities with regard to the landing of goods in Canadian territory, and the supplying of the natives with liquor. A police station, under the Mounted Police, will be established for policing and controlling the country. Officers, under the departments of Marine and Fisheries, Mounted Police and the Interior, have been sent with instructions from the heads of the different departments. The management of the vessel, the purchase of the outfit and the movements of the ship "Neptune," have been directed by the Minister of Marine and Fisheries, and he will make all necessary arrangements for the return of the vessel to St. John, Nfld., or Halifax.

The expedition was sent with the expectation of securing information not now in the possession of the Dominion Government, relating to the northern waters and certain sections of the coast around Hudson Bay, Welcome Sound, Baffin Bay and Cumberland Bay. 


\section{PART II.}

\section{FISHERIES}

\section{Extent of Coast.}

The Fisheries of Canada are the most extensive of the world, extending on our immense sea-coast line, besides innumerable lakes and rivers. The eastern sea-coast of the Maritime Provinces, from the Bay of Fundy to the Strait of Belle Isle, covers a distance of 5,600 miles, while the western seacoast of British Columbia is reckoned at 7, 180 miles; the fresh water area of that part of the Great Lakes belonging to Canada is computed at 72,700 square miles, not including the numerous lakes of Manitoba and the North-West Territories, all stocked with excellent species of good fish.

To better demonstrate the importance of this branch of the Department, it is sufficient to give the enormous aggregate values of the five principal commercial fishes, which are as follows :

From the year 1869 to 1901 inclusive.

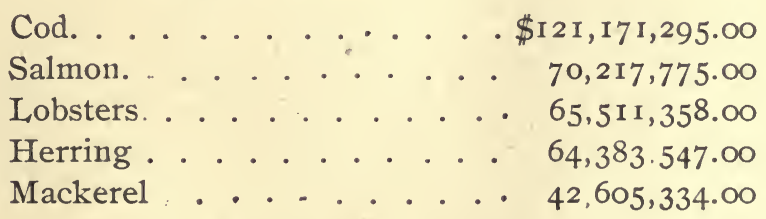

\section{Capital Invested in the Fisheries of Canada and Number of Men Engaged Therein.}

In 1895 the fishing fleet comprised I,221 vessels, valued at $\$ 2,318,290.00$, manned by 9,804 sailors, and 34,268 fishing boats, valued at $\$ \mathrm{r}, \mathrm{I04}, 057.00$, used by $6 \mathrm{r}, 530$ fishermen, employing over six million fathoms of nets and other fishing gear, aggregating a capital of $\$ 9,253,848.00$.

In $190 \mathrm{I}$ there were $\mathrm{I}, 23 \mathrm{I}$ fishing vessels, valued at $\$ 2,4 \mathrm{I} 7$,680.00 , and 38,186 fishing boats, estimated at $\$ 1,212,297.00$, 
manned by 78,290 fishermen, using fishing gear aggregating in value of $\$ 1 x, 49 \tau, 300.00$, showing an invested capital of more than two million dollars over that in 1895 .

\section{Fishing Industry.}

The Canadian Fishery Industry is one of great value and capable of enormous development. It is gratifying to record its steady increase and improvement, which shows it to be proceeding on a healthy and permanent basis, notwithstanding the fluctuations which are to be looked for in a vocation so hazardous and so amenable to the inflences of wind and weather.

In 1895 the aggregate yield of the fisheries of the Dominion was valued at $\$ 20,199,338.00$, while in I90I, (the last published statistics), they yielded $\$ 25,737, \mathrm{I} 53.00$.

This betterment may be ascribed to some extent to fluctuations in the general yield; but the following comparative statements indicate a considerable development in some of the principal branches of the industry :

SALMON CANNING IN BRITISH COLUMBIA.

\begin{tabular}{|c|c|c|c|c|c|}
\hline \multirow{2}{*}{ Year } & & Canneries. & & $\begin{array}{l}\text { Salmon } \\
\text { Pack. }\end{array}$ & \multirow{2}{*}{$\begin{array}{l}\text { Persons } \\
\text { employed }\end{array}$} \\
\hline & No. & Value. & Cans. & Value. & \\
\hline $\begin{array}{l}1895 \\
1901\end{array}$ & $\begin{array}{l}49 \\
77\end{array}$ & $\begin{array}{r}\$ 980,000 \\
1,540,000\end{array}$ & $\begin{array}{l}28,847,101 \\
59,866,176^{*}\end{array}$ & $\begin{array}{r}\$ 2,884,710 \\
5,986,617\end{array}$ & $\begin{array}{l}12,478 \\
18,942\end{array}$ \\
\hline Increase & 18 & $\$ 560,000$ & $31,019,075$ & $3,101,907$ & 6,464 \\
\hline
\end{tabular}

* NorE: The season of 1901 was the best packing season experienced 


\begin{tabular}{|c|c|c|c|c|c|c|c|c|}
\hline \multirow{8}{*}{ 它 } & '[?7о L & 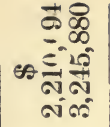 & 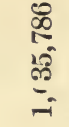 & \multirow{9}{*}{\multicolumn{2}{|c|}{ 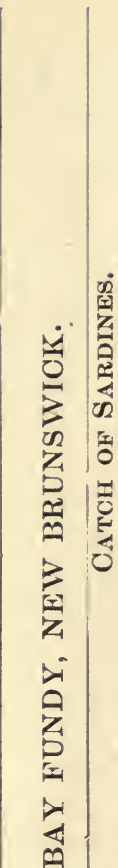 }} & \multirow{3}{*}{$\frac{\dot{0}}{\stackrel{0}{z}}$} & 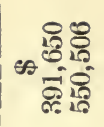 & $\begin{array}{l}0 \\
0 \\
0 \\
0 \\
0 \\
0\end{array}$ \\
\hline & $\cdot$ •əท & 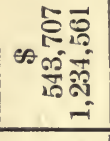 & $\begin{array}{l}\overrightarrow{8} \\
0 \\
8 \\
8\end{array}$ & & & & \multirow[t]{2}{*}{ 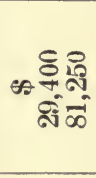 } & \multirow[t]{2}{*}{. } \\
\hline & \multirow{2}{*}{ 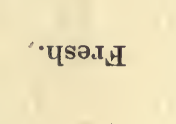 } & \multirow{2}{*}{ 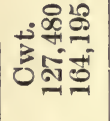 } & \multirow{2}{*}{ 苞 } & & & & & \\
\hline & & & & & & \multirow{2}{*}{ 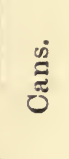 } & \multirow{2}{*}{ 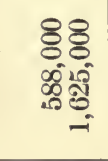 } & \multirow{2}{*}{\begin{tabular}{l}
8 \\
8 \\
5 \\
\multirow{2}{9}{} \\
-1
\end{tabular}} \\
\hline & \multirow{2}{*}{ •วn[ย $\Lambda$} & \multirow{2}{*}{ 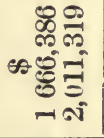 } & \multirow{2}{*}{ 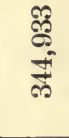 } & & & & & \\
\hline & & & & & & \multirow{2}{*}{ 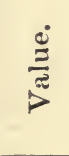 } & \multirow{2}{*}{ 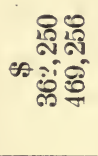 } & \multirow{2}{*}{$\begin{array}{l}8 \\
8 \\
5 \\
5\end{array}$} \\
\hline & \multirow{2}{*}{ •suBJ qI } & \multirow{2}{*}{ 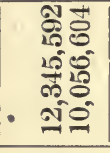 } & \multirow{2}{*}{ 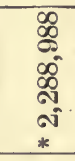 } & & & & & \\
\hline & & & & & & \multirow[b]{2}{*}{ 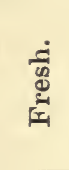 } & \multirow[b]{2}{*}{ 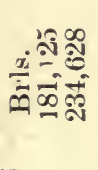 } & \multirow[b]{2}{*}{ 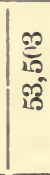 } \\
\hline \multirow{5}{*}{ 恋 } & •[ย]०] & 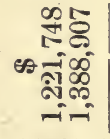 & 霄 & & & & & \\
\hline & $\cdot{ }^{\cdot}$ ən ${ }^{e} \Lambda$ & 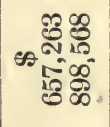 & 疍 & 吕 & & 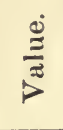 & 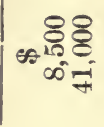 & $\begin{array}{l}\text { 号 } \\
\text { : } \\
\text { กิ }\end{array}$ \\
\hline & •sdexL & 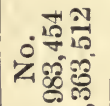 & 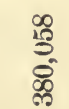 & 㝵 & $\dot{H}$ & 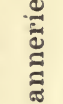 & $\dot{z}^{\circ} \infty x_{0}$ & N \\
\hline & 'әп[ॄ $\Lambda$ & 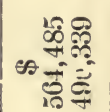 & $\begin{array}{l}0 \\
\frac{\pi}{5}\end{array}$ & 究 & $D_{i}$ & 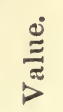 & 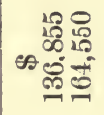 & \begin{tabular}{|l}
12 \\
8 \\
65 \\
5 \\
ज
\end{tabular} \\
\hline & 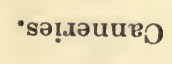 & 之ं & สิ & \multirow{4}{*}{ 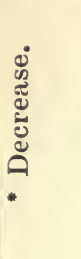 } & \multirow{2}{*}{\multicolumn{2}{|c|}{$\stackrel{\stackrel{\infty}{*}}{\vec{\theta}}$}} & \multirow[t]{2}{*}{ గె口 } & \multirow[t]{2}{*}{ ติ } \\
\hline & \multirow{2}{*}{$\begin{array}{l}\text { pəरoldtuə } \\
\text { suosxəd }\end{array}$} & \multirow{2}{*}{$\begin{array}{l}020 \\
102 \\
1020 \\
012\end{array}$} & \multirow{2}{*}{ ลิ } & & & & & \\
\hline & & & & & \multirow{2}{*}{\multicolumn{2}{|c|}{ ฮ્ర }} & \multirow{2}{*}{$\stackrel{20}{\infty}$} & : \\
\hline & $\approx \cdot \pi 8 \partial \Lambda$ & 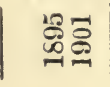 & 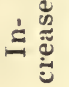 & & & & & פ్ّ \\
\hline
\end{tabular}


The aggregate values of the other most important kinds of commercial fishes in the Dominion, in comparison are as foilows :-

\section{5}

Cod

Herring.

Mackerel

Haddock

Whitefish...................

Trout.

Smelts

Halibut

Pickerel

Hake.

Pollock

Oysters
$\$ 3,638,519.00$

$2,786,516.00$ $736,655.00$ $444,703.00$ $767,307.00$ $702,589.00$ $451,108.00$ $270,901.00$ $303,296.00$ $210,856.00$ $148,767.00$ $192,292,00$
1901

$\$ 4,039,394.00$ $1,865,394.00$ $1,372,459.00$ $782,163.00$ $783,459.00$ $663,642.00$ $485,874.00$ $394,521.00$ $339,686.00$ $304,212.00$ $227,218.00$ $179,488.00$

\section{Fishery Licenses}

The Fishery Licenses have also steadily increased since 1895, notwithstanding that since the decision of the Judicial Committee of the Imperial Privy Council, the Provinces of Ontario and Quebec, in so far as the inland waters and rivers of the latter are concerned, have assumed the issuing of Fishery Licenses as a Provincial function, following the establishment of the right of disposal of proprietary interests.

The following statement shows a present total issue of 11,610 Fishery Licenses, against 8,427 in 1895 :

FisheRY LICENSES.

\section{5}

1901 Increase

British Columbia 1,801 North-West Territories.............. 174 Manitoba. 4,156 697 $5 \mathrm{C} 6$

The West.........2,297

5,359 3,062 
New Brunswick .................... 3,775

Nova Scotia.......................... 479

3,654 Increase

Prince Edward.Island... .......... 804

Gulf of St. Lawrence ............. 272

Lobster Licenses.................... 800

Fish Breeding.

In 1895 there were only fourteen Fish Hatcheries, from which was distributed about two hundred million fry, while in 1903, there are twenty-one such establishments, and the distribution of fry will be increased fifty per cent over that of 1896, viz: about three hundred millions. These hatcheries are located as follows :

5 in Quebec,

5 in New Brunswick,

3 in Ontario,

3 in Nova Scotia,

3 in British Columbia,

$I$ in Manitoba,

$\mathbf{I}$ in Prince Edward Island.

\section{Lobster Breeding in Pounds.}

The question of giving every assistance to the replenishing of the Lobster fishery, both by artificial means and by following nature as closely as possible, has received careful attention by the Department, and as result the experiment of enclosing live female Lobsters in pounds during the open season, and releasing them when the close season commenced, has been tried and pruved very successful.

The experiment was conducted in a pound owned by $\mathrm{Mr}$. H. E. Baker and located at Forchu, in Cape Breton' County, 
N. S., and resulted in releasing, when the close season commenced, some 50,000 female lobsters which had been secured during the open season. Some of these lobsters spawned whilst in captivity and from this source alone it is estimated millions of young lobsters found their way from the pound to their natural haunts in the sea, and as 10,000 eggs to a lobster is a fair average, it is fully expected that a series of these pounds, together with the good work being done by the Lobster Hatcheries, should not only keep up the present supply, but fully restore this valuable fishery to ițs original standard.

\section{Close Seasons for Fish.}

The different close seasons for the various species of fish, with the protection of which this Department is charged, have, generally speaking, been but slightly changed; but in the case of the Lobster Fishery a complete new code of regulations, establishing seven separate sectional close seasons and three different size limits, in conformity with geographical and other Iocal conditions, was in 1899 adopted, as the result of a Commission appointed in 1898 to inquire into the Canadian lobster industry.

The following is a table showing the various close seasons for fish in the several Provinces of the Dominion. 

TABLE OF CLOSE SEASONS FOR FISH

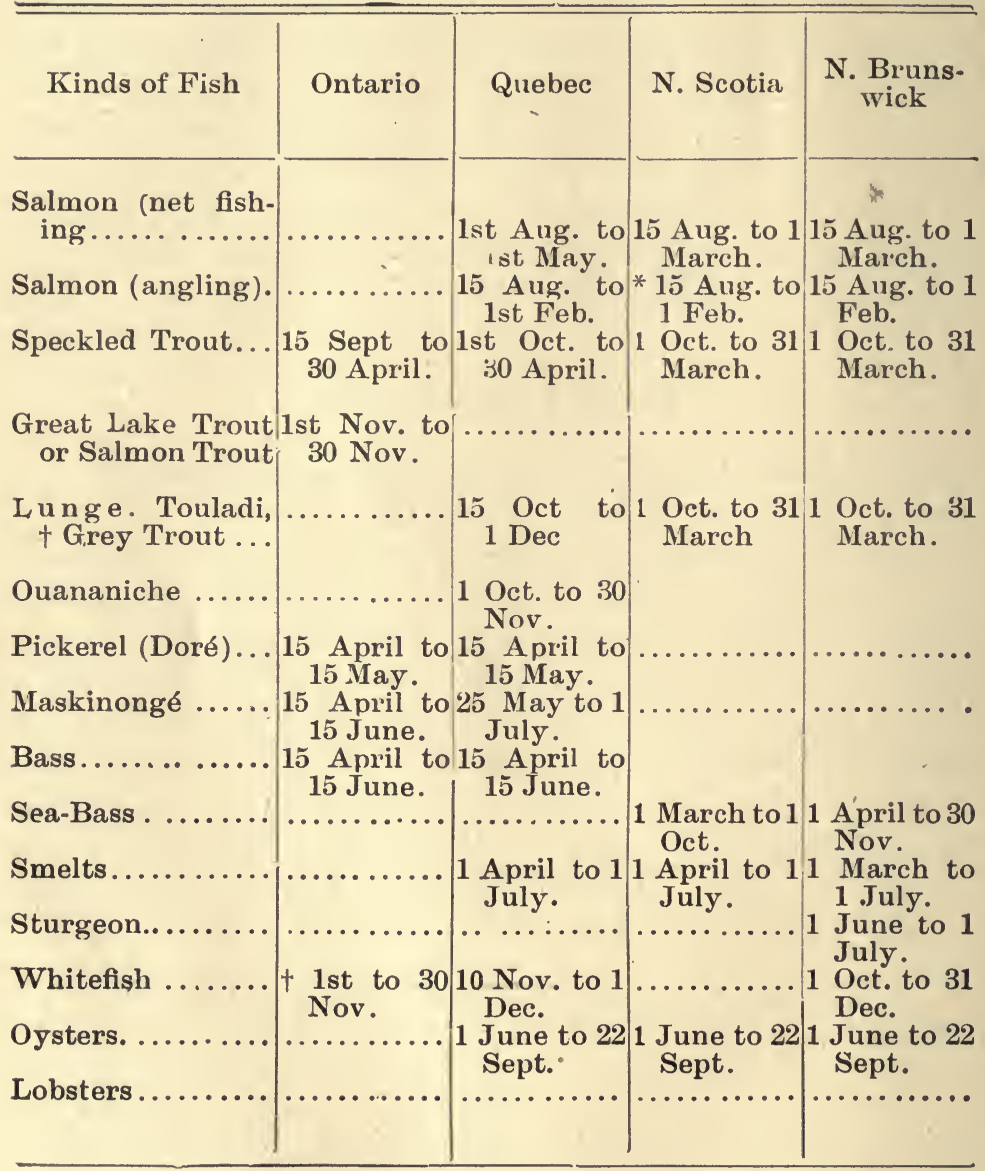

Norz.-A general weekly close-time is provided in addition to special close-seasons. 
INFFRCE 1sT OCTOBER, 1903

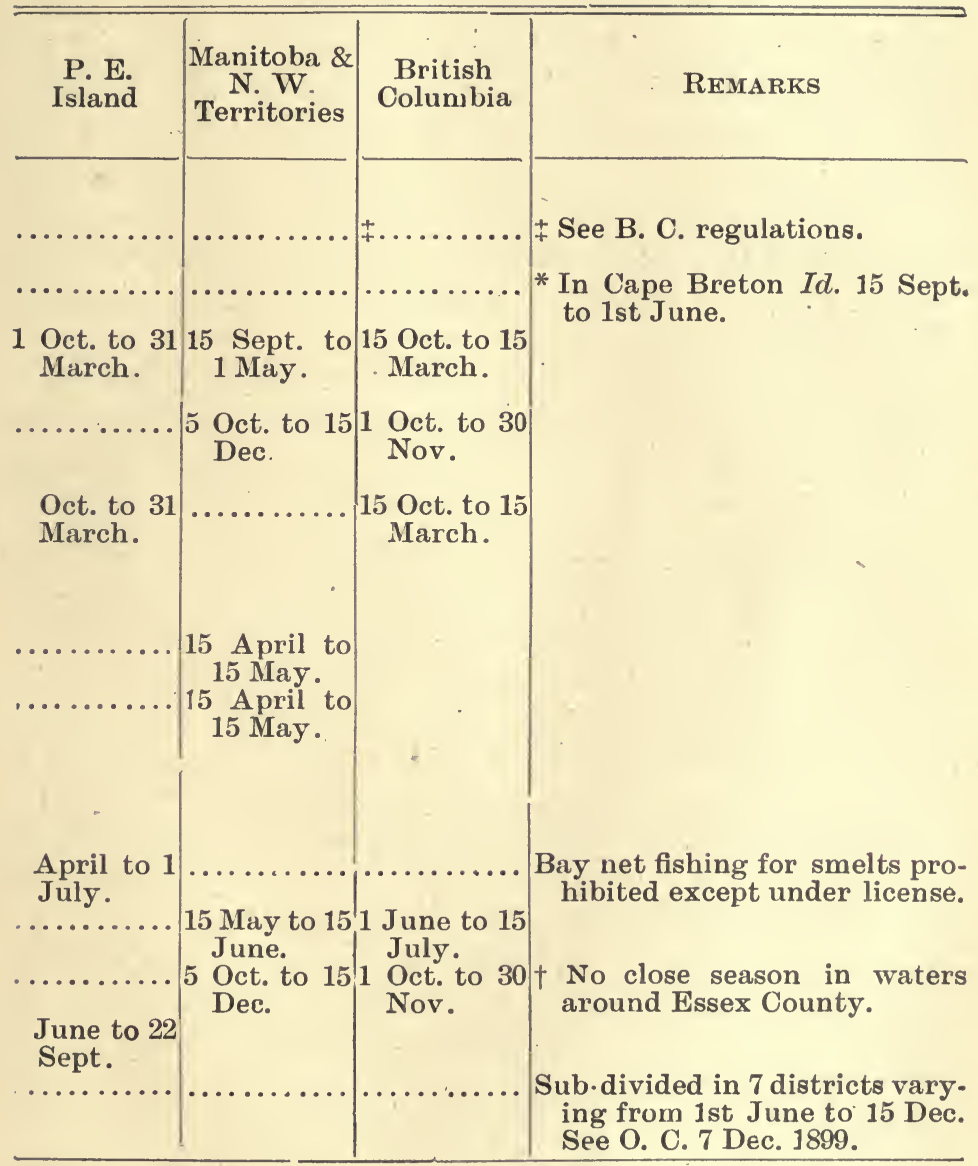




\section{Herring Curing and Packing.}

The curing and packing of herring for shipment from Canada, has been under consideration with a view of improving the methods employed by fish curers and dealers. No doubt Canada is not reaping the full benefit of her extensive herring fisheries, as pickled herring, as a commercial article, is depreciated by the inferior methods of handling the fish from their capture on the fishing grounds until they are placed on the market.

I have become convinced by an examination of the reports which I have caused to be made, that Canadian herring cured and packed more in the manner of the Scotch and other European fish curers, will greatly enhance the value of our herring fisheries. A comparison of prices of Canadian herring, with European herring, sold in the United States, is very convincing proof that Canada is loosing heavily by the present inferior methods of catching and pickling these fish.

For example, in a recent issue of the New York Fishing Gazette, Canadian pickled herring in New York market are quoted from $\$ 4.25$ to $\$ 6.00$ per barrel, while in the same market Scotch, English, Irish, Norwegian and Dutch herring are quoted from \$II.OO to \$I2.50 per barrel and are smaller fish than the Canadian herring and not any finer in flavour. In a letter recently written to a Halifax gentlemen by a dealer in Chicago it is stated that 25,000 barrels of Dutch and Norwegian cured herring are annually imported into Chicago. The dealer referred to is of the opinion that all or nearly all of Chicago's needs in cured herring might be supplied by Canada.

It is proposed to ship $\$ I, 000$ or $\mathrm{I,200}$ barrels of herring cured in Canada by the Scotch method to New York, Chicago and Germany as an experiment.

In order to carry out a scheme for the improvement of catching and curing herring in the Dominion, a Scotch expert has been employed to visit the different fishing localities in Quebec and the Maritime Provinces, to report upon the feasibility of adopting a practical method of effectively teaching our fishing population how to produce a superior article of 
pickled herring. The introduction of the system of giving practical instruction and information, will begin in the early spring, by employing a staff of Scotch and Canadian fishermen, fish curers and coopers. Canso, N. S., has been selected as the station from which to act as a centre, being convenient for fishermen in the Lower Provinces who fish on the Atlantic Coast, Gulf of St. Lawrence and Northumberland Strait. It is intended to employ a steamer to collect herring from the traps and weirs and to carry on deep fishing by drift netting. If the experience is successful it is probable that other stations will be established for the purpose of extending the improved method of catching and pickling fish, to several districts in the Dominion.

\section{Bait Cold Storage for Deep Sea Fishermen.}

Of the many efforts made by the Dominion Government to foster and promote the sea fisheries, the most recent, and in many respects, the most remarkable, is that of providing, under Federal auspices, facilities for the storage and preservation of bait in refrigerators. The subject of cold storage for bait, and of fishery products generally, has for over twenty years engaged the attention of the Department of Marine and Fisheries.

The phase of the matter which was regarded as most weighty by the Department was that relating to the bait supply of the fishermen. Season after season the lack of bait, not merely hampered, but absolutely stopped fishing operations at the most important part of the season.

The fishermen may form and incorporate themselves into associations in different localities, when the Government will contribute one-half the cost of the construction and equipment of Bait Freezers, and for a period of three years will pay a bonus of $\$ 5.00$ per ton on the amount of bait frozen.

Thus the aid is confined to localities where the fishermen are prepared to cooperate with the Government.

Since the inauguration of this scheme in 1899 , twenty four of these Fishermen's Bait Freezers have been established in different fishing centres in the Atlantic Provinces. Last year 
about ${ }^{5} 50$ tons of bait were thus frozen and stored, of which $70^{\circ} \%$ was utilized by the fishermen.

These Freezers have been erected principally in Nova Scotia, and Prince Edward Island, one having been established in New Brunswick and one in Quebec.

\section{Fisheries Protection Service.}

The following is a comparative statement of the vessels and cruisers employed in the Fisheries Protection Service of Canada for the years 1895 and 1903 .

In 1895, the Acadia, La Canadienne, Curlew, Constance, Vigilant, Kingfisher, Petrel and Dolphin.

In addition to these the "Stanley" and "Aberdeen" were used when considered necessary. The "Quadra" on the Pacific coast was also used now and then.

Two of these vessels, the "Kingfisher" and the "Vigilant," were sailing schooners, the "Vigilant" being a capture 1 United States' fishing vessel, named the "Highland Light," which was afterwards turned into one of ourcruisers. The officers and crews of these vessels numbered approximately two hundred.

In the year 1903, the following vessels formed the Fisheries Protection Fleet :

Acadia, La Canadienne, Curlew, Kingfisher, Osprey, Brant and Constance on the Atlantic Coast; Kestrel on the British Columbia Coast and Petrel on the Great Lakes.

In addition to these there are four large steam sea-going patrol boats which are mainly used in looking after our own lobster fishing. The officers and crews amounted to about 260 .

In addition to the above, provision has been made for building two 16 knot cruisers, one for service on the Great Lakes and the other on the Atlantic Coast. This will increase the number of officers and crew to about 360 .

To show the necessity of a fast cruiser on the Atlantic Coast it will be only necessary to say that there were I,239 entries made by United States' fishing schooners in our ports during the year 1902, comprising a total net tonnage of 19,897 tons with nearly 5,000 men on board. 
These vessels require continual looking after, and it is very necessary to have something fast to do it with. On the Great Lakes there is continual poaching going on, and the "Petrel " is not fast enough to cope with the United States' fishing tugs.

On the Atlantic Coast we have a regular system of reporters, this year numbering about $5^{3}$ stations, who every day report the movements of the United States' fishermen and also the fish, and at what ports, bait and ice can be found, which our fishermen find of great benefit; more especially this year when bait has been so scarce; and it means that they simply have to go to the nearest telegraph office, look at the bulletin board which is displayed at every station and find out where bait can be procured.

\section{Expenditure}

The following table shows the expenditure of the Fishery Branch for the last fiscal year and i 895-6.

Service

Expenditure

\begin{tabular}{ccr} 
& $1895-6$ & $1901-2$ \\
Fisheries (proper)...........\$ & 96,961 & $\$ 104,880$ \\
Fish-breeding.............. & 38.050 & 79,891 \\
FisheriesProtection Serv, & 102,021 & 152,825 \\
Fishing bounty............ & 163,567 & 155,942 \\
Miscellaneous Expe'dit're & 20,203 & 56,131 \\
\cline { 2 - 2 } Total............... & 420,805 & $\frac{549,670}{}$ \\
& Increase & $\$ 128,865$
\end{tabular}

NOTE. - This increase has taken place notwithstanding that since 1899 , the expenditure in the Province of Ontario has decreased by over 80 p. c. and in Quebec by nearly 50 per cent, owing to the withdrawing of our local staff of officers in these provinces.

This pamphlet is submitted to the public with the confident expectation that it will be of interest to those engaged in shipping and others interested in Marine and Fisheries matters.

RAYMOND PREFON'TAINE, Minister of Marine and Fisheries.

Ottawa, Ist February I904. 


\section{TABLE OF CONTENTS.}

A

Aids to navigation .......... 3 Acetylene Gas experiments with I5

\section{B}

Buoy Service between Montreal and Quebec, Improvements... 7 Buoy Service, Great Lakes and Georgian Bay............ II Buoys, total number in Dominion II Bait cold storage............ 28

Coast Buoys Maritime Provinces and British Columbia........ Io Close Seasons for Fish ....... 24 " "Table of........25

\section{D}

Dominion Steamers built and purchased since $1896 . . . . . .$. I

$\mathbf{E}$

Expenditure, tota1...........

$\mathbf{F}$

Fisheries.............. I9

" capital invested and men engagéd....... I9

Fishing Industry, Aggregate Yield .................. 20

Fishing Licences ............. 22

Fish Breeding $\ldots \ldots \ldots \ldots \ldots \ldots, 23$

Fishery Protection Service..... 28

Fisheries Expenditure, comparative statement between 18956 and $1901-2 \ldots \ldots \ldots \ldots \ldots 30$

\section{G}

Gas Buoys added in $1903 . . .$. . Gas Buoys proposed in the St. Lawrence River............

Ga Buoys between Montreal and Kingston. ............

Gas Storeholders............ 9

Gas Buoys proposed for N. S... Io
II

Hydrographic Survey .... .... I3 Hudson Bay Expedition....... I8 Herring, Curing and Packing. . 27

L

Lighthouses to be put in operation.................. 5

Lightships constructed......... 6 Lighthouses, total number in the Dominion.............. 7

Life-saving stations......... I4

Lobster Industry Maritime Provinces................ 2I

Lobster Breeding in Pounds... 23

MI

Meteorological Service ........ I4

$\mathbf{N}$

Naval Reserve \& Navigation Schools ................ I7

(

Ocean and River Service....... II Ocean and River Service, total expenditure............ I2

\section{$\mathbf{P}$}

Progress and development of Department since $1896 \ldots . . .3$

Steamboat Inspection $\ldots . . . .16$ Salmon Canning in British CoInmbia................ 20

$\mathbf{T}$

Tidal Survey............. 13

Values of Fish, comparative statement between I895 \& I90I.. 22

\section{w}

Winter Communication....... I5 Wrecks and Casualties St. Lawrence River, investigations.... I6 





